\title{
2 Does Minor Crops (Bajra, Barley and Jowar) have 3 Significant Association to Agriculture Sector of 4 Pakistan? An Empirical Investigation
}

\author{
Abdul Rehman 1,*, Abbas Ali Chandio ${ }^{2}$ \\ ${ }^{1}$ Research Center of Agricultural-Rural-Peasants, Anhui University Hefei, China; abdlrehman@ahu.edu.cn \\ ${ }^{2}$ College of Economics, Sichuan Agricultural University Chengdu, China; alichandio@sicau.edu.cn \\ * Correspondence: abdlrehman@ahu.edu.cn; Tel.: 008615256556123
}

\begin{abstract}
This paper investigates and explores the minor crops production in Pakistan and its association with the agricultural gross domestic product. The agriculture sector of Pakistan has a rich contribution to the economic growth and development. Like major crops; minor crops also have a vital role to boost up the agriculture sector. Time span data was used in this study and it was collected from the Economy Survey of Pakistan annual reports. Augmented Dickey-Fuller (ADF) unit root test and Ordinary Least Square (OLS) method was used to analyze the data and results were interpreted by employing the Johansen co-integration test. Study results reveal that bajra, barely and jowar has a significant impact on the agricultural gross domestic product, while the total cropped area has a negative impact on AGDP. On the basis of the study results, we recommend the policy implications.
\end{abstract}

Keywords: Pakistan; bajra; barley; jowar; crops production; agricultural gross domestic product

\section{Introduction}

The agriculture sector of Pakistan is playing an important role for the economic development; it is contributing about $19 \%$ to the gross domestic product (GDP), and employing about $43 \%$ of the labor force of the country and also has rich contribution to provide raw materials for the several value-added sectors. It is playing a dominant role in the economic development, poverty alleviation and food security. The fast development of urban areas in Pakistan specifies the demand the high-value consumable products such as vegetables, fruits, dairy products, and meat is increasing. The government is working to enhance and raise the productions these products by implementing new policies to boost rural growers' through investment in the major infrastructure, including dependable transportation networks and other structure chunks in contemporary supply chains (Rehman et al. 2015; GOP 2016).

The agricultural sector consists of five sub-areas, including major crops, minor crops, livestock, forestry and fisheries. Agricultural grain and cereal crops include rice, corn, wheat, bajra, sweet sorghum and barley (Raza and Mehboob 2012; Anwar et al. 2015). Minor crops in Pakistan include Bajra, barely and Jowar (sweet sorghum). Major crops include such as cotton, wheat, rice, corn, sugar cane, etc.; minor crops have also contributed to the development of the Pakistans agricultural sector. Bajra (Pennisetum glaucum) is the most widely cultivated type of millet. Africa and South Asia have been growing since the prehistoric times. Barley is also a cool season, fast-growing, an annual cereal crop that can be used as a feed, as well as, to cover crops to enhance soil fertility. After corn, wheat, rice, and soybeans, it ranks fifth in world food production (Manning and Fuller 2011; Miralles et al. 
2001; Hussain et al. 2004; Zeid 2011; Ghanbari et al. 2012). Jowar (Sorghum) is a cultivated tropical grain grass. Today, jowar is cultivated around the world in warm climates. After corn, wheat, barley and rice, it is considered the fifth largest grain crop in the world. Farmers prefer to grow jowar varieties based on their ability and acclimate to numerous temperatures, rainfall, soil types and environmental situations (Mekbib et al. 2006). Furthermore, being as an important food and pasture crop, jowar (sorghum) having a dominant role in the production of raw materials for the production of fiber, starch, dextrose syrup, alcohol, biofuels, and other products. Jowar is planting in the semi-arid areas and more than half populations of the world is associated with this crop, and is considered the staple food of millions hungry and poor people (Mehmood and Gulfraz 2008). During the year 2016-17, bajra crop production increased about $1.7 \%$ as compared to the same period in the previous year. Similarly, barley, jowar, mastard and tobacco crops production also increased with the ratio of $9.8 \%, 7.5 \%, 3.2 \%$, and $2.6 \%$ respectively, which showed a negative growth as compared to same period in the previous year due to decrease in sown area (GOP 2016).

Moreover, it is reported that between 1995 and 2020, the supply of agricultural water is expected to decrease in developing countries from $72 \%$ to $62 \%$, and on a global scale, the decline of $87 \%$ to $73 \%$ is also projected (Khan and Blackwell, 2006). Since Pakistan is an agricultural country, the shortage of agricultural water have a negative impact on its economy, as this sector subsidizes directly its gross domestic product and more than $40 \%$ labor is linkage directly or indirectly associated with this sector (GOP 2008). Despite the severe crisis in the agricultural sector, including power shortages, weak infrastructure, developed agricultural markets and insufficient funding in this sector (Jan and Khan 2012). It is imperative to increase agricultural production efficiency and use resources more efficiently, mainly inland, irrigation, and appropriate use of major inputs and available credit facilities (Iqbal and Ahmad 2002; Dong and Featherstone 2012; Faridi and Tahir 2015; Rehman et al. 2017).

The irrigation system in the Pakistan is the largest in the world for the agricultural production. The production of food is mainly dependent on the irrigation; it provides more than $90 \%$ production in the grain crops (FAO 2015). Compared with other developing countries, the agricultural production has declined, but its growth rate is maintained through technological advancement, grants and agrarian research. As a result, the annual growth rate of the agricultural sector in the economy is considerable 5.1\% (Ahmed and Gill 2007; Rehman et al. 2016). The main focus of this study was on the minor crops production including bajra, barley and jowar and its association with AGDP (agricultural gross domestic product). Besides the introduction section, the remaining sections of the paper include; methodology, results and discussion and final is conclusion and policy implications. The trends of the variables including area under bajra, area under barely and area under jowar are reported in figure 1. The production trend of bajra, barley, and jowar are presented in figure 2.

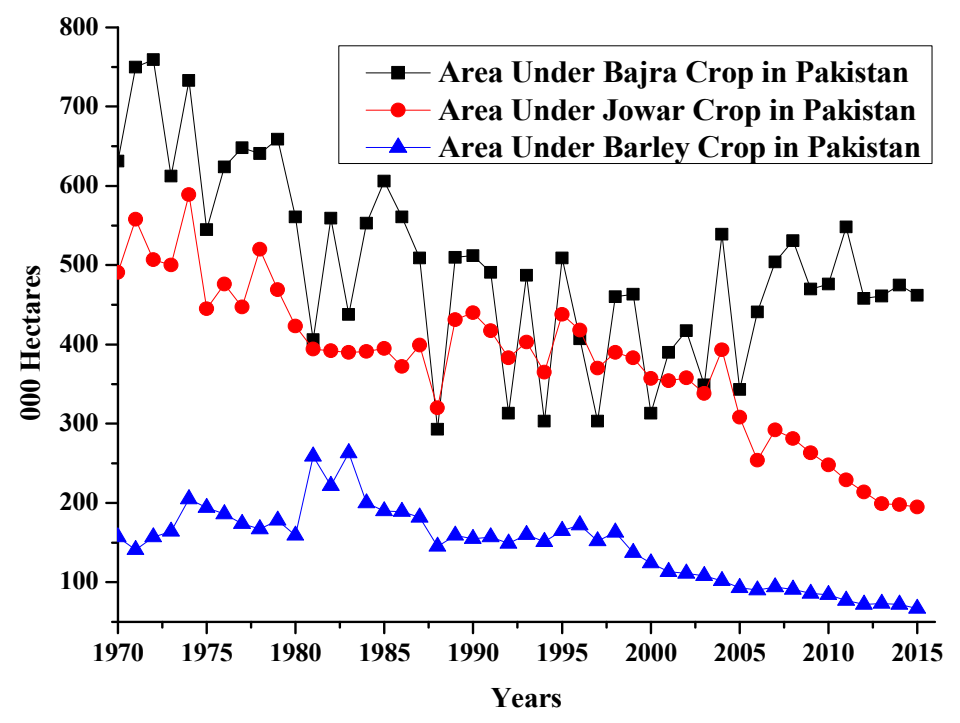

Fig 1. Area under minor crops in Pakistan from 1970-2015. 


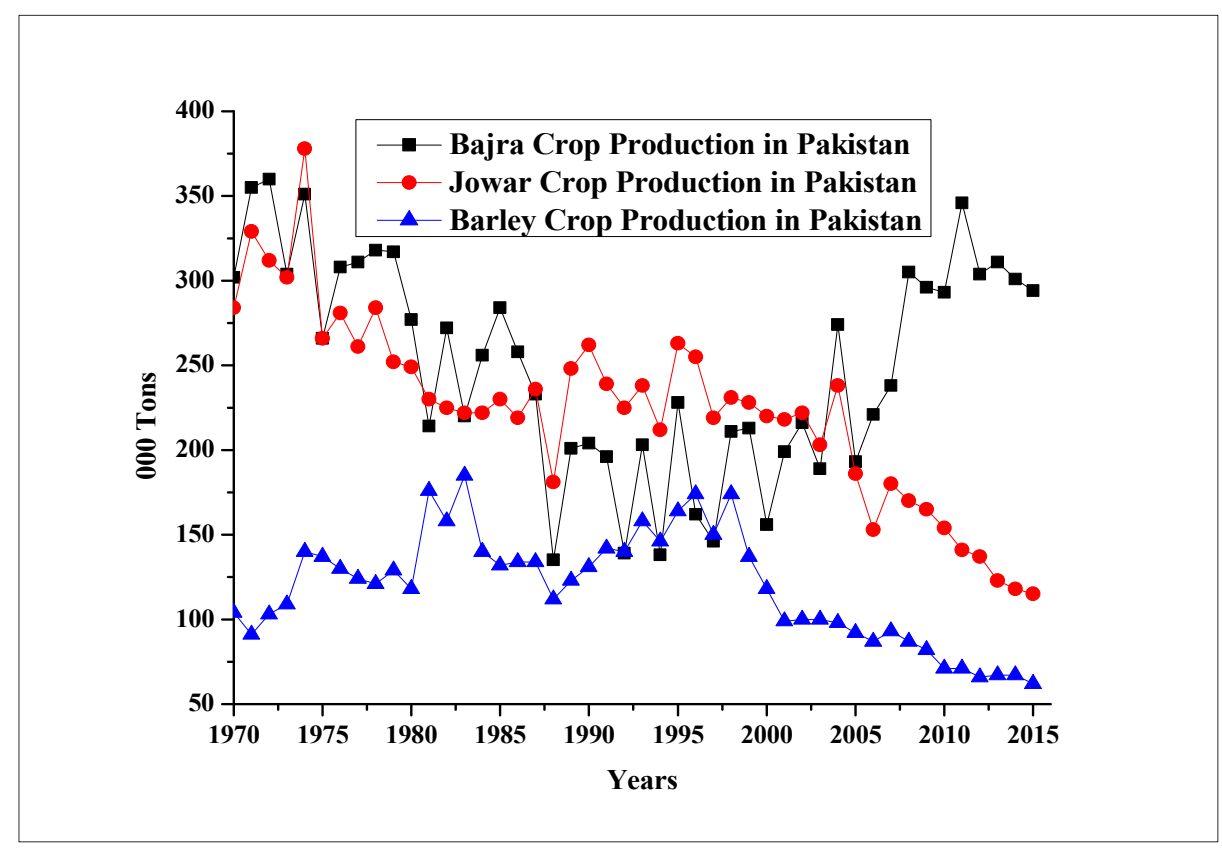

Fig 2. Minor crops production in Pakistan from 1970-2015.

\section{Methodology}

\subsection{Data Sources}

In this paper time span data was used from 1970-2015, and it was gathered from the Economy Survey of Pakistan. The variables used in this paper are minor crops including bajra, barley, jowar, total cropped area and agricultural gross domestic product.

\subsection{Empirical Model}

The following model was specified to check the relationship between minor crops, total cropped area and agricultural gross domestic product:

Where,

$$
M=f\left(R_{1}, R_{2}, R_{3}, R_{4}\right)
$$

$$
\mathrm{M}=\mathrm{AGDP}, \mathrm{R}_{1}=\mathrm{BAJRA}, \mathrm{R}_{2}=\mathrm{BARLEY}, \mathrm{R}_{3}=\mathrm{JOWAR}, \mathrm{R}_{4}=\mathrm{TOTAL} \text { CROPPEDAREA }
$$

We can also write Equation (1) as:

$$
\text { AGDP }=\mathrm{f}(\text { BAJRA, BARLEY, JOWAR, TOTAL CROPPED AREA) }
$$

The log-linear stipulations of the variables have been used and the following equation has been estimated (equation 3);

$$
\begin{aligned}
\ln (\text { AGDP })=\phi_{0} & +\phi_{1} \ln (\text { BAJRA })+\phi_{2} \ln (\text { BARLEY })+\phi_{3} \ln (\text { JOWAR }) \\
& +\phi_{4} \ln (\text { TOTAL CROPPED AREA })+\mu_{\mathrm{t}}
\end{aligned}
$$

Where AGDP indicates the agricultural GDP in million rupees, $\phi_{0}=$ natural logarithm of $A$, the intercept; $\ln (\mathrm{BAJRA})$ indicates the natural logarithm of the production output of bajra (in 000 tonnes); $\ln$ (BARLEY) indicates the natural logarithm of production output of barley (in 000 tonnes); 
102

103

104

105

106

107

108

109

110

111

112

113

114

115

116

117

118

\begin{tabular}{|c|c|c|c|c|c|}
\hline Variables & Mean & Median & Maximum & Minimum & Std. Dev. \\
\hline AGDP & 12.37545 & 11.71063 & 14.60880 & 10.95063 & 1.393530 \\
\hline LNBAJRA & 5.488980 & 5.549068 & 5.886104 & 4.905275 & 0.271154 \\
\hline LNBARLEY & 4.739877 & 4.803988 & 5.220356 & 4.127134 & 0.291463 \\
\hline LNJOWAR & 5.381146 & 5.422723 & 5.934894 & 4.744932 & 0.265962 \\
\hline LNTOTALAREA & 6.910184 & 6.948868 & 7.331060 & 6.584791 & 0.211070 \\
\hline Observations & 46 & 46 & 46 & 46 & 46 \\
\hline
\end{tabular}

119

120

121

Note: ${ }^{* * *}$ shows $1 \%$ of significance level

122

$\ln$ (JOWAR) indicates the natural logarithm of the production output of jowar (in 000 tonnes); $\ln$ (TOTAL CROPPED AREA) indicates the natural logarithm of total area used for the crop production (in 000 hectares); and $\mu_{\mathrm{t}}$ is the error term.

\subsection{Ordinary Least Square Method}

The predictive ability of the model is measured by employing the OLS (Ordinary Least Square) method and it provides the parameter for the short-run relationship and for the analysis of the long-run among the variables Johansen co-integration test was applied.

\section{Results and Discussion}

This section may be divided by subheadings. It should provide a concise and precise description of the experimental results, their interpretation as well as the experimental conclusions that can be drawn.

\subsection{Descriptive Analysis and Results of ADF Unit Root Test}

ADF (Augmented Dickey-Fuller) unit root test was applied to check the stationarity of the variables. Table 1 reports result of the descriptive statistics and table 2 represents the ADF test results. The descriptive statistics results revealed that the minor crops including bajra, barely and jowar has a substantial impact on the AGDP.

Table 1. Descriptive Statistics of the Variables

Table 2. ADF Unit Root Test including (Trend and Intercept)

\begin{tabular}{|c|c|c|c|c|}
\hline \multirow{2}{*}{ Variables } & \multicolumn{2}{|c|}{ At level } & \multicolumn{2}{c|}{ First Difference } \\
\cline { 2 - 5 } & t-Statistic & Critical values & t-Statistic & Critical values \\
\hline LNAGRGDP & -2.123962 & $1 \%-4.175640$ & $-6.967640^{* * *}$ & $1 \%-4.180911$ \\
& $(0.5189)$ & $5 \%-3.513075$ & $(0.0000)$ & $5 \%-3.515523$ \\
& & $10 \%-3.186854$ & & $10 \%-3.188259$ \\
\hline LNBAJRA & -1.636601 & $1 \%-4.180911$ & $-7.725612^{* * *}$ & $1 \%-4.186481$ \\
& $(0.7619)$ & $5 \%-3.515523$ & $(0.0000)$ & $5 \%-3.518090$ \\
& & $10 \%-3.188259$ & & $10 \%-3.189732$ \\
\hline LNBARLEY & -1.861383 & $1 \%-4.175640$ & $-8.884715^{* * *}$ & $1 \%-4.180911$ \\
& $(0.6577)$ & $5 \%-3.513075$ & $(0.0000)$ & $5 \%-3.515523$ \\
& & $10 \%-3.186854$ & & $10 \%-3.188259$ \\
\hline LNJOWAR & -3.067747 & $1 \%-4.175640$ & $-7.383166^{* * *}$ & $1 \%-4.186481$ \\
& $(0.1263)$ & $5 \%-3.513075$ & $(0.0000)$ & $5 \%-3.518090$ \\
& & $10 \%-3.186854$ & & $10 \%-3.189732$ \\
\hline
\end{tabular}

\subsection{Co-integration Test Results}

Johansen co-integration test results including trend and intercept are presented in the table 3. Test results revealed a long-run equilibrium among the study variables. Trace statistic and the 
125

126

127

128

134

135

136

137

Max-Eigenvalue statistic revealed one (1) co-integrating equation at the $1 \%$ and $5 \%$ level of significance.

Table 3. Results of the Johansen Cointegration test using Trace Statistic and Maximum Eigenvalue

\begin{tabular}{|c|c|c|c|c|}
\hline \multicolumn{5}{|c|}{ Trace Statistic } \\
\hline $\begin{array}{c}\text { Null } \\
\text { Hypothesis }\end{array}$ & $\begin{array}{l}\text { Alternative } \\
\text { Hypothesis }\end{array}$ & $\begin{array}{c}\text { Test } \\
\text { Statistic }\end{array}$ & $5 \%$ Critical value & Prob. ${ }^{* *}$ \\
\hline $\mathrm{HO}: \mathrm{r} \leq 0$ & $\mathrm{H} 1: \mathrm{r}>0$ & $73.47170^{* *}$ & 69.81889 & 0.0248 \\
\hline $\mathrm{HO}: \mathrm{r} \leq 1$ & $\mathrm{H} 2: \mathrm{r}>1$ & 34.36530 & 47.85613 & 0.4820 \\
\hline $\mathrm{H} 0: \mathrm{r} \leq 2$ & H3: $r>2$ & 19.75163 & 29.79707 & 0.4398 \\
\hline $\mathrm{H} 0: \mathrm{r} \leq 3$ & $\mathrm{H} 4: \mathrm{r}>3$ & 9.838457 & 15.49471 & 0.2934 \\
\hline $\mathrm{HO}: \mathrm{r} \leq 4$ & H5: $r>4$ & 0.308912 & 3.841466 & 0.5783 \\
\hline \multicolumn{5}{|c|}{ Maximum Eigenvalue Statistic } \\
\hline $\begin{array}{c}\text { Null } \\
\text { Hypothesis }\end{array}$ & $\begin{array}{l}\text { Alternative } \\
\text { Hypothesis }\end{array}$ & $\begin{array}{c}\text { Test } \\
\text { Statistic }\end{array}$ & $5 \%$ Critical value & Prob.** \\
\hline $\mathrm{H} 0: \mathrm{r} \leq 0$ & $\mathrm{H} 1: \mathrm{r}>0$ & $39.10640^{* * *}$ & 33.87687 & 0.0108 \\
\hline $\mathrm{H} 0: \mathrm{r} \leq 1$ & $\mathrm{H} 2: \mathrm{r}>1$ & 14.61368 & 27.58434 & 0.7781 \\
\hline $\mathrm{H} 0: \mathrm{r} \leq 2$ & H3: $r>2$ & 9.913169 & 21.13162 & 0.7528 \\
\hline $\mathrm{H} 0: \mathrm{r} \leq 3$ & $\mathrm{H} 4: \mathrm{r}>3$ & 9.529545 & 14.26460 & 0.2447 \\
\hline $\mathrm{H} 0: \mathrm{r} \leq 4$ & H5: $r>4$ & 0.308912 & 3.841466 & 0.5783 \\
\hline
\end{tabular}

Note: ${ }^{* *}$ and ${ }^{* * *}$ denote rejection of the hypothesis at $5 \%$ and $1 \%$ significance level

\subsection{Results of Regression Analysis}

Table 4 reports the results of the regression. The value of R-squared was 0.886 , and the adjusted R-squared was 0.874 . The F-statistic computed value was 79.72613 with a $p$-value of 0.0000 . The model demonstration shows the overall goodness to fit.

Table 4. Regression Analysis

\begin{tabular}{|l|c|c|c|c|}
\hline \multicolumn{5}{|c|}{ Dependent Variable: LNAGDP } \\
\hline \multicolumn{5}{|c|}{ Method: Least Squares } \\
\hline Included Observations: 46 \\
\hline Variable & Coefficient & Std. Error & t-Statistic & Prob. \\
\hline LNBAJRA & $49.05655^{* * *}$ & 2.756994 & 17.79349 & 0.0000 \\
\hline LNBARLEY & $3.899168^{* * *}$ & 0.883675 & 4.412446 & 0.0001 \\
\hline LNJOWAR & 0.048103 & 0.617026 & 0.077959 & 0.9382 \\
\hline LNTOTALAREA & $2.709878^{* * *}$ & 0.968824 & 2.797079 & 0.0078 \\
\hline R-squared $=0.886081$ & $-10.54875^{* * *}$ & 1.787755 & -5.900558 & 0.0000 \\
\hline F-statistic $=79.72613$ & Adjusted R-squared $=0.874967$ \\
\hline Durbin-Watson stat $=1.722401$ & Prob(F-statistic) $)=(0.0000)$ \\
\hline
\end{tabular}

Table 4 demonstrates the results of the regression analysis, and results shows that the coefficient of the bajra has a significant and positive relationship with AGDP. The results also show that the barely also has a positive impact on the AGDP, but statistically is non-significant with having p-value 0.9382. Similarly results also revealed that jowar crop also has a positive and significant relationship with the AGDP. The results of the total cropped area shows a negative association with the agricultural gross domestic product. It was not expected but may be the reason 
145

146

147

148

149

150

151

152

153

154

155

156

157

158

159

160

161

162

163

164

165

166

167

168

169

170

171

172

173

174

\section{5}

176

177

178

179

180

181

182

183

184

185

186

187

188

189

190

191

192

193

for the negative relationship variations in the climatic condition, land degradation and water availability.

\section{Conclusion and Policy Implications}

The agriculture sector in the Pakistan has dominant role in the economic development and also has a rich contribution to boost the economy. In this paper, we investigated the relationship of minor crops including bajra, barley and jowar and their contributions to the AGDP (agricultural gross domestic product). Agriculture sector is measured as the mainstay of Pakistan economy; it has a rich contribution to the economic development. ADF unit root test and OLS method was applied on the time span data to measure the stationarity. Johansen co-integration test was applied to interpret the results. The study results show that the bajra crop has a positive and significant impact on the AGDP. Results also show that the barley crop has a positive but non-significant influence on the agricultural gross domestic product. Similarly, jowar crop also has a constructive and substantial impact on the agricultural gross domestic product, but the coefficient of the total cropped area has a negative impact on the AGDP. According to the study results, it is necessary that Pakistan's government should implement new policies and subsidy schemes to boost the sector of these minor crops. Following policy implications should be implemented:

- Adoption and development of new verities.

- Attention needed to reduce post-harvest losses.

- Provide easy access to the farmers to obtain agricultural credits to purchase seeds and fertilizers.

- To enhance the water supply inefficient way through proper and better water management.

- To make an investment in the scientific research, development, and extension.

- Provide easy access to the markets for buying seeds, fertilizers, farm mechanization, credit, water.

Author Contributions: A. R. conceived the study, collected the data, estimated the econometric model and drafted the manuscript. A.A.C read and made suggestions and finalized the manuscript. All authors read and approved the final manuscript.

Funding: This research received no external funding.

Conflicts of Interest: The authors declare no conflict of interest.

\section{References}

Rehman, A., Jingdong, L., Shahzad, B., Chandio, A.A., Hussain, I., Nabi, G. and Iqbal, M.S., 2015. Economic perspectives of major field crops of Pakistan: An empirical study. Pacific Science Review B: Humanities and Social Sciences, 1(3), pp.145-158.

GOP, 2016. Economic survey of Pakistan 2016-2017. Agricultural statistics of Pakistan. Ministry of Food Agriculture and Livestock Division, Islamabad.

Raza, S.A., Ali, Y. and Mehboob, F., 2012. Role of agriculture in economic growth of Pakistan. International Research Journal of Finance and Economics, (83):181-185.

Anwer, M., Farooqi, S. and Qureshi, Y., 2015. Agriculture sector performance: An analysis through the role of agriculture sector share in GDP. Journal of Agricultural Economics, Extension and Rural Development, 3(3), pp.270-275.

Manning, K., Pelling, R., Higham, T., Schwenniger, J.L. and Fuller, D.Q., 2011. 4500-Year old domesticated pearl millet (Pennisetum glaucum) from the Tilemsi Valley, Mali: new insights into an alternative cereal domestication pathway. Journal of Archaeological Science, 38(2), pp.312-322.

Miralles, D.J., Ferro, B.C. and Slafer, G.A., 2001. Developmental responses to sowing date in wheat, barley and rapeseed. Field Crops Research, 71(3), pp.211-223.

Hussain, A.B.I.D., Ghaudhry, M.R., Wajad, A., Ahmed, A., Rafiq, M.U.H.A.M.M.A.D., Ibrahim, M.U.H.A.M.M.A.D. and Goheer, A.R., 2004. Influence of water stress on growth, yield and radiation use efficiency of various wheat cultivars. Intl. J. Agric. Biol, 6, pp.1074-1079. 
Zeid, I.M., 2011. Alleviation of seawater stress during germination and early growth of barley. International Journal of Agriculture: Research and Review, 1(2), pp.59-67.

Ghanbari, A., Babaeian, M., Esmaeilian, Y., Tavassoli, A. and Asgharzade, A., 2012. The effect of cattle manure and chemical fertilizer on yield and yield component of barley (Hordeum vulgare). African Journal of Agricultural Research, 7(3), pp.504-508.

Mekbib, F., 2006. Farmer and formal breeding of sorghum (Sorghum bicolor (L.) Moench) and the implications for integrated plant breeding. Euphytica, 152(2), pp.163-176.

Mehmood, S., Bashir, A., Ahmad, A., Akram, Z., Jabeen, N. and Gulfraz, M., 2008. Molecular characterization of regional Sorghum bicolor varieties from Pakistan. Pak. J. Bot, 40(5), pp.2015-2021.

GOP, 2016. Economic survey of Pakistan 2016-2017. Agricultural statistics of Pakistan. Ministry of Food Agriculture and Livestock Division, Islamabad.

Khan, S., Tariq, R., Yuanlai, C. and Blackwell, J., 2006. Can irrigation be sustainable?. Agricultural Water Management, 80(1-3), pp.87-99.

GOP, 2008. Economic survey of Pakistan 2008-2009. Agricultural statistics of Pakistan. Ministry of Food Agriculture and Livestock Division, Islamabad.

Jan, I. and Khan, H., 2012. Factors responsible for rural household participation in institutional credit programs in Pakistan. African Journal of Business Management, 6(3), pp.1186-1190.

Rehman, A., Chandio, A.A., Hussain, I. and Jingdong, L., 2017. Is credit the devil in the agriculture? The role of credit in Pakistan's agricultural sector. The Journal of Finance and Data Science, 3(1-4), pp.38-44.

Iqbal, M., Khan, M.A. and Ahmad, M., 2002. Adoption of recommended varieties: A farm-level analysis of wheat growers in irrigated Punjab. The Pakistan Development Review, pp.29-48.

Dong, F., Lu, J. and Featherstone, A.M., 2012. Effects of credit constraints on household productivity in rural China. Agricultural Finance Review, 72(3), pp.402-415.

Faridi, M.Z., Chaudhry, M.O. and Tahir, N., 2015. Institutional Credit and Agricultural Productivity: Evidence from Pakistan. Pakistan Journal of Life and Social Sciences, 13(3), pp.183-188.

FAO, 2015. Food and Agriculture Organization, The state of food security in the world. FAO. Rome.

Ahmed, T. and Gill, Z.A., 2007. Role of agricultural credits and efficiency of commercial banks of Pakistan. International Journal of Agriculture and Biology (Pakistan).

Rehman, A., Jingdong, L., Khatoon, R., Hussain, I. and Iqbal, M.S., 2016. Modern agricultural technology adoption its importance, role and usage for the improvement of agriculture. Life Science Journal, 14(2), pp.70-74. 